\title{
EFFECT OF PLANT SOURCE ORGANIC FERTILIZERS ON YIELD AND IT'S COMPONENTS OF LINSEED CULTIVARS
}

A. A. Mohammed*

Researcher
J. M. Abbas

Prof.
M. H. K. Al-Baldawi

Prof.

\section{ABSTRACT}

Dept. of Field Crops - Coll. of Agric. Engineering Sci. - University of Baghdad

A field trials was carried out during winter season of 2017-2018 and 2018-2019 at Field Crops Department - College of Agricultural Engineering Sciences - University of Baghdad / Jadriyah to study the effect of organic fertilizers of plant source (compost) on yield and it's components of linseed cultivars. Randomized complete block design (RCBD) arranged according to split plots used with three replicates. The trials included four weed sources organic fertilizer \{Malva rotundifolia L., Eichhronia crassipes (Mart) Solms, Glycyrrhiza glabara L. and Silybum marianum L.\} and NPK chemical fertilizer $\left(90 \mathrm{Kg} \mathrm{N} \mathrm{ha}^{-1}, 120 \mathrm{Kg} \mathrm{P} \mathrm{ha}^{-1}\right.$ and $\left.80 \mathrm{Kg} \mathrm{K} \mathrm{ha}^{-1}\right)$ in addition to control treatment (without fertilizer) within main plots and three linseed cultivars (Syrian, Egyptian and Iraqi local) within sub plots. The results showed that the Syrian cv. produced the highest number of capsules 106.67 and 103.75 capsule plant ${ }^{-1}$, number of seeds 8.03 and 8.33 seed capsule ${ }^{-1}$, seed yield 1.03 and 1.12 mton ha $^{-1}$, biological yield 4.24 and $4.50 \mathrm{mton} \mathrm{ha}^{-1}$ and harvest index 24.21 and $24.82 \%$, while the Egyptian cv. gave highest means of 1000 seeds weight 6.73 and $7.22 \mathrm{~g}$ for the two seasons, respectively. The fertilizer treatments significantly affected on the all studied characters. The plant at the NPK treatment produced the highest number of capsules 105.48 and 99.74 capsule plant $^{-1}$, number of seeds 7.89 and 7.95 seed capsule ${ }^{-1}$ without significant differences on the G. glabara L. treatment which was superior in the seed yield 1.04 and $1.03 \mathrm{mton} \mathrm{ha}^{-1}$, biological yield 4.18 and $4.32 \mathrm{mton} \mathrm{ha}^{-1}$ and harvest index 24.57 and $23.65 \%$ without significant differences with NPK treatment for the two seasons, respectively. The interaction between the two factors had significant effect on all characters except 1000 seeds weight at first season.

Key words: Linum usitatissimum L., compost, different weed sources, plant nutrition.

*Part of Ph.D. dissertation of the $1^{\text {st }}$ author.

مجلة العلوم الزراعية العراقية -2020 :51(عدد خاص):95-86 محمد وآخرون

تأثير الأسمدة العضوية ذات المصدر النباتي في الحاصل ومكوناته لبذور أصناف من الكتان

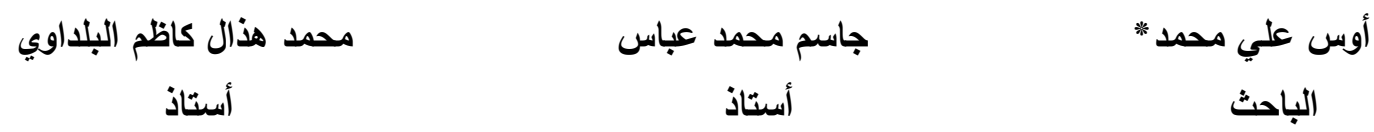

قسم المحاصيل الحقلية - كلية علوم الهزيدة الزراعية - جامعة بغداد

نفذت تجرية حقلية في الموسم الثتوي لسنتي 2017-2018 و2018-2019 في محطة الأبحاث الزراعية التابعة لقسم المحاصيل الحقلية - كلية علوم الهندسة الزراعية - جامعة بغداد / الجادرية لمعرفة تأثير التسميد العضوي ذو المصدر النباتي في مكونات الحاصل وحاصل البذور لأصناف

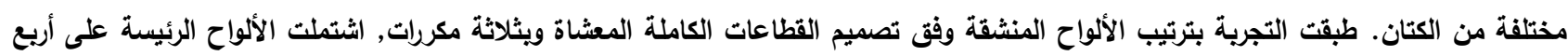

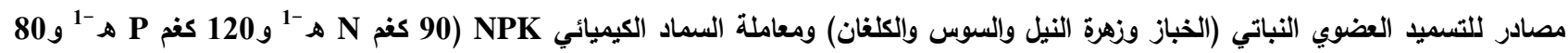
كفم K هـ -1') فضلا عن معاملة المقارنة (من دون تسميد), بينما اشتملت الألواح الثانوية ثلاثة أصناف من الكتان (السوري والمصري والعراقي المحلي). أظهرت النتائج تفوق الصنف السوري معنويا وأعطى أعلى النتائج لعدد الكبسولات

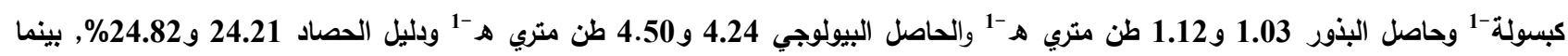
تفوق الصنف المصري بإعطائه أعلى متوسط لوزن 1000 بذرة بلغ 6.73 و و7.22 غم لموسمي الاراسة بالتتابع. أظهرت النتائج أن معاملة إضافة وله

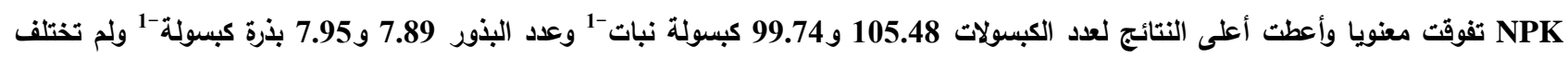
معنويا عن معاملة إضافة السماد العضوي الناتج عن تحلل السوس التي أعطت أعلى النتائج لحاصل البذور 1.04 و 1.03 طن متري هـ -1.

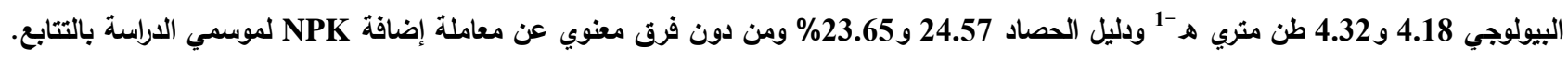
كان تأثير التذاخل بين عاملي الدراسة معنويا في الصفات المدروسة جميعها باستثناء وزن 1000 بذرة في الموسم الأول فقط. الكلمات المفتاحية: .Linum usitatissimum L, الكومبوست, مصادر أدغال مختلفة, تغذية النبات. "البحث مستل من أطروحة دكتوراه للباحث الأول.

*Received:17/8/2019, Accepted:10/11/2019 


\section{INTRODUCTION}

Linseed Linum usitatissimum L. a dual purpose industrial crop, grown at different parts of the world to obtain fiber and oil. Linseed seeds contain a high percentage of oil ranging from $30-45 \%$ with high quality and medicinal importance, due to its unsaturated fatty acids such as oleic, linoleic and linolenic (18). The cultivation of this crop in Iraq suffers from several problems, including limited cultivars suitable for environmental conditions, which led to the dependence of agriculture on the experimental scale on the local cultivar, this requires the study of other cultivars with the local cultivar taking advantage of the genetic variation of these cultivars and their interaction with environmental conditions to reach the best environmentally adapted cultivars. The cultivation of the appropriate cultivar is an important factor in obtaining high productivity of the economic yield, but the cultivar alone isn't enough to achieve this, but requires the application of some field practices aimed at stimulating its genetic and physiological ability. The application of chemical fertilizers is one of these processes that provide the necessary nutrients during the growth and development of plants $(13,16)$. However, the rapid loss of these nutrients from some soils and high cost as well as the environmental pollution caused by unplanned applications led to the idea of adopting alternatives to improve soil fertility, reduce the cost of production and reduce the level of environmental pollution by moving towards an agricultural system such as the application of organic fertilizers of plant source (weeds), which is characterized by, low economic cost, protecting of the environment from pollution and improvement of the physical and chemical properties of the soil as well as representing the nutrients balance to provide the basic nutrient requirements of the plant during its various stages can be one of the best management paractices $(1,2,8,9,20)$. The aims of this research are to study the effect of organic fertilizers of plant source (compost) on yield and it's components of linseed cultivars.

\section{MATERIALS AND METHODS}

A field trials were carried out during winter season of 2018 and 2019 at Field Crops Department - College of Agricultural Engineering Sciences - University of Baghdad/ Jadriyah in a clay loam soil as shows their physical and chemical properties at Table 1, to study the effect of organic fertilizers of plant source (compost) on yield and it's components of linseed cultivars. Randomized complete block design RCBD arranged according to split plots used with three replicates.

Table 1. Physical and chemical soil properties in 2018 and 2019

\begin{tabular}{|c|c|c|c|}
\hline Trait & 2018 & 2019 & Unit \\
\hline Sand & 381 & 396 & \\
Loam & 241 & 260 & gm Kg Soil $^{-1}$ \\
Clay & 378 & 354 & \\
Ec & 3.85 & 3.72 & ds m $^{-1}$ \\
pH & 7.09 & 7.14 & --- \\
O.M & 6.1 & 5.6 & g Kg Soil $^{-1}$ \\
Total CaCO & 233.2 & 248.6 & g Kg Soil $^{-1}$ \\
Ca & 18.24 & 18.86 & \\
K & 1.18 & 1.04 & \\
Mg & 11.48 & 10.62 & \\
Na & 8.31 & 8.97 & \\
Cl & 22.47 & 23.11 & \\
HCO & $\mathbf{5 . 4 6}$ & 5.88 & \\
CO & Nill & Nill & \\
SO & 9.42 & 8.18 & \\
Available N & 63 & 46 & \\
Available P & 16 & 11 & mg Kg Soil \\
Available K & 117 & 104 & \\
\hline
\end{tabular}

The trail included four decomposed plant organic fertilizers $\{M$. rotundifolia L., $E$. crassipes (Mart) Solms, G. glabara L. and $S$. marianum L.\} and NPK chemical fertilizer 90 $\mathrm{Kg} \mathrm{N} \mathrm{ha}{ }^{-1}, 120 \mathrm{Kg} \mathrm{P} \mathrm{ha}^{-1}$ and $80 \mathrm{Kg} \mathrm{K} \mathrm{ha}^{-1}$ (14), in addition to control treatment (without fertilizer) within main plots and three linseed cultivars (Syrian, Egyptian and Iraqi local) within sub plots. Soil management especially plowing were carried out as required, and then the experiment land was divided into 54 experimental units, the area of each 
experimental unit was $4 \mathrm{~m}^{2}$ which contained 10 lines, $20 \mathrm{~cm}$ apart. The seeds of the linseed cultivars were sown at a seed rate of $40 \mathrm{~kg} \mathrm{ha}^{-1}$ (11) on the 12 and 13 Nov. for the two seasons, respectively. Crop management were carried out as needed, and the plants were harvested after the appearance of maturity signs. Organic fertilizers were prepared according to the method reported by Ali and Shaker (3), the chemical properties of these organic fertilizer were shows at Table 2.

\section{Studied traits}

Number of main branches plant ${ }^{-1}$ from ten plant randomly taken from the guarded lines for each experimental unit at the harvest stage. Number of sub branches plant ${ }^{-1}$ for ten plant randomly taken from the guarded lines for each experimental unit at the harvest stage. Number of capsules plant ${ }^{-1}$ was calculated. Number of seeds capsule ${ }^{-1}$ was calculated by dividing the number of seeds capsules ${ }^{-1}$ by the number of capsules ten plants ${ }^{-1}$. Weight of 1000 seeds ( $\mathrm{g}$ ) calculated after mixing the seeds of the harvested plants from each experimental unit and taking 1000 seeds from them randomly and then weighed. A sample of $1 \mathrm{~m}^{2}$ of each experimental unit was harvested and the straw was isolated from the seeds, weighed and converted from $\mathrm{gm} \mathrm{m}^{-2}$ to mton $\mathrm{ha}^{-1}$ for seed yield. A sample of $1 \mathrm{~m}^{2}$ of each experimental unit was harvested, dried, weighed and converted from $\mathrm{g} \mathrm{m}^{-2}$ to mton $\mathrm{ha}^{-1}$ for biological yield. Harvest index was calculated by the following equation (10):

$$
\text { Harvest index }=\frac{\text { Seed Yield }}{\text { Biological yield }} \times 100
$$

The data were analyzed statistically by using Gnestat program, and least significant difference (LSD) test at 0.05 probability level was used to compare the treatment means (17).

\section{RESULTS AND DISCUSSION}

\section{Number of main branches plant ${ }^{-1}$}

The results at the Table 3 indicate that the cultivars were significantly different in the number of main branches. The Syrian cv. gave the highest means 5.86 and 6.04 branch plant $^{-1}$ compared with Egyptian cv. which gave the lowest means 4.35 and 4.90 branch plant $^{-1}$ for the two seasons, respectively. These results indicate that the Syrian cv. was more responsive to environmental conditions and invested towards stimulating the growth of lateral buds and then an increasing the number of main branches (5). Data at the Table 3 indicate that the number of main branches was significantly affected by fertilizer treatments. The G. glabara L. treatment gave the highest means 5.59 and 5.97 branch plant $^{-1}$ without significant differences with the NPK treatment 5.46 and 5.93 branch plant ${ }^{-1}$, while the control treatment gave the lowest means 4.55 and 4.95 branch plant $^{-1}$ for the two seasons, respectively.

Table 2. Chemical properties of organic fertilizers of plant source (weeds) in 2017-2018 and 2018-2019

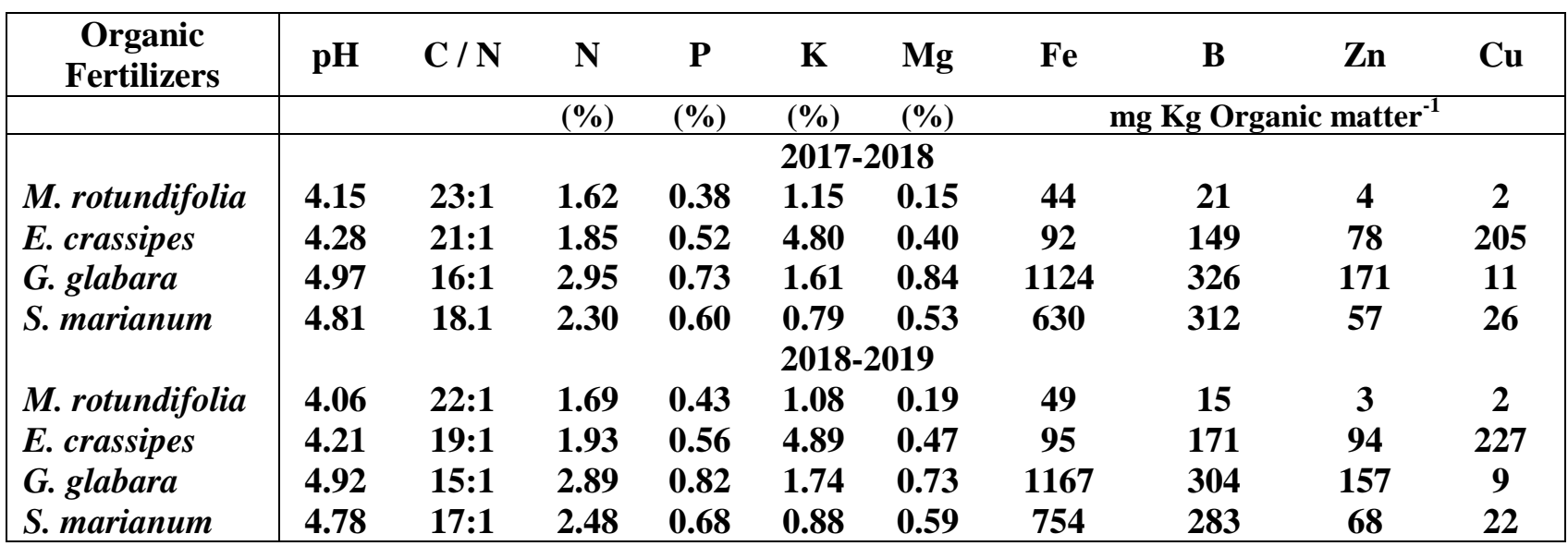


The reason of the superiority of G. glabara L. treatment could be due to their role in an increasing the amount of essential nutrients for growth and development of the plant (Table 2), especially in a good fertile soil (Table 1) which lead to promote the emergence of lateral buds and stimulating their growth and then an increasing the number of branches (15). The interaction between two factors had significant effect on the number of main branches. The Syrian cv. with G. glabara L. treatment gave the highest values 6.57 and 6.73 branch plant $^{-1}$ without significant differences on the same cultivar with NPK treatment 6.25 and 6.49 branch plant ${ }^{-1}$, while the Egyptian cv. with control treatment gave the lowest values 3.83 and 4.14 branch plant $^{-1}$ for the two seasons, respectively (Table 3 ).

Table 3. Effect of different treatments on the number of main branches plant ${ }^{-1}$ for the seasons 2018 and 2019

\begin{tabular}{|c|c|c|c|c|}
\hline \multicolumn{5}{|c|}{$2017-2018$} \\
\hline \multirow{2}{*}{$\begin{array}{l}\text { Fertilizer } \\
\text { treatments }\end{array}$} & \multicolumn{3}{|c|}{ Linseed cultivar's } & \multirow{2}{*}{ Mean } \\
\hline & Syrian & Egyptian & Iraqi & \\
\hline Control & 5.04 & 3.83 & 4.79 & 4.56 \\
\hline NPK & 6.25 & 4.78 & 5.34 & 5.46 \\
\hline M. rotundifolia & 5.63 & 4.01 & 4.45 & 4.70 \\
\hline E. crassipes & 5.94 & 4.14 & 5.31 & 5.13 \\
\hline G. glabara & .576 & 4.62 & 5.59 & 5.59 \\
\hline S. marianum & 5.74 & 4.72 & 5.22 & 5.23 \\
\hline LSD 0.05 & & 0.36 & & 0.27 \\
\hline Mean & 5.86 & 4.35 & 5.12 & \\
\hline LSD 0.05 & & 0.15 & & \\
\hline \multicolumn{5}{|c|}{ 2018-2019 } \\
\hline Control & 5.48 & 4.14 & 5.23 & 4.95 \\
\hline NPK & 6.49 & 5.36 & 5.94 & 5.93 \\
\hline M. rotundifolia & $\mathbf{5 . 5 7}$ & 4.62 & 5.14 & 5.11 \\
\hline E. crassipes & 5.72 & 5.30 & 5.58 & 5.54 \\
\hline G. glabara & 6.73 & 5.11 & 6.07 & 5.97 \\
\hline S. marianum & 6.27 & 4.85 & 5.82 & 5.65 \\
\hline LSD 0.05 & & 0.34 & & 0.24 \\
\hline Mean & 6.04 & 4.90 & 5.63 & \\
\hline LSD 0.05 & & 0.14 & & \\
\hline
\end{tabular}

\section{Number of sub branches plant ${ }^{-1}$}

The results at the Table 4 show that there are significant differences among cultivars in the number of sub branches. The Syrian cv. gave the highest means 22.87 and 21.11 branch plant $^{-1}$ compared with Egyptian cv. which gave the lowest means 16.26 and 16.63 branch plant $^{-1}$ for the two seasons, respectively. The superiority of the Syrian cv. could be due to superior in the number of main branches per plant (Table 3). These results are in agreement with Al-Sudani (5). The NPK treatment was significantly superior in the number of sub branches 21.75 and 20.33 branch plant $^{-1}$ without significant differences with the $G$. glabara L. treatment 21.51 and 20.90 branch plant $^{-1}$, whereas the control treatment gave the lowest means 16.77 and 15.90 branch plant $^{-1}$ for the two seasons, respectively (Table 4). The superiority of the NPK or G. glabara L. treatments could be due to superior in the number of main branches plant ${ }^{-1}$ (Table 3 ).

Table 4. Effect of different treatments on the number of sub branches plant ${ }^{-1}$ for the seasons 2018 and 2019

\begin{tabular}{|c|c|c|c|c|}
\hline \multicolumn{5}{|c|}{ 2017-2018 } \\
\hline \multirow{2}{*}{$\begin{array}{l}\text { Fertilizer } \\
\text { treatments }\end{array}$} & \multicolumn{3}{|c|}{ Linseed cultivar's } & \multirow{2}{*}{ Mean } \\
\hline & Syrian & Egyptian & Iraqi & \\
\hline Control & 18.83 & 14.11 & 17.38 & 16.77 \\
\hline NPK & 25.43 & 18.23 & 21.58 & 21.75 \\
\hline M. rotundifolia & 20.83 & 14.85 & 18.15 & $\mathbf{1 7 . 9 4}$ \\
\hline E. crassipes & 24.01 & 15.36 & 20.77 & 20.05 \\
\hline G. glabara & 26.18 & 16.84 & 21.52 & 21.51 \\
\hline S. marianum & 21.92 & 18.16 & 20.52 & 20.20 \\
\hline LSD 0.05 & & 2.05 & & 1.48 \\
\hline Mean & 22.87 & 16.26 & 19.99 & \\
\hline LSD 0.05 & & 0.84 & & \\
\hline \multicolumn{5}{|c|}{ 2018-2019 } \\
\hline Control & 17.65 & 13.12 & 16.93 & 15.90 \\
\hline NPK & 23.23 & 18.63 & 19.14 & 20.33 \\
\hline M. rotundifolia & 18.55 & 15.69 & 16.16 & 16.80 \\
\hline E. crassipes & 20.12 & 18.42 & 18.06 & 18.87 \\
\hline G. glabara & 24.76 & 17.16 & 20.78 & 20.90 \\
\hline S. marianum & 22.37 & 16.79 & 18.99 & 19.38 \\
\hline LSD 0.05 & & 2.26 & & 1.45 \\
\hline Mean & 21.11 & 16.63 & 18.34 & \\
\hline LSD 0.05 & & 0.92 & & \\
\hline
\end{tabular}

The interaction between two factors had significant effect on the number of sub branches. The Syrian cv. with G. glabara L. treatment had the highest values 26.18 and 24.76 branch plant $^{-1}$ without significant differences on the same cultivar with NPK treatment 24.43 and 23.23 branch plant $^{-1}$, while the Egyptian cv. with control treatment had the lowest values 14.11 and 13.12 branch plant $^{-1}$ for the two seasons, respectively. 


\section{Number of capsules plant $^{-1}$}

The differences in the number of capsules among cultivars have been found significant (Table 5). The Syrian cv. was produced the highest means 106.67 and 103.75 capsule plant $^{-1}$ compared with Egyptian cv., which had the lowest means 83.24 and 79.88 capsule plant $^{-1}$ for the two seasons, respectively. The superiority of the Syrian cv. could be due to the superiority in number of main and sub branches per plant (Tables 3 and 4). These results are in agreement with Al-Sudani (5) who found that the increase in number of main and sub branches plant ${ }^{-1}$ led to an increase in the number of capsules plant ${ }^{-1}$. Data at the Table 5 show that the number of capsules were significantly affected by fertilizer treatments. The NPK treatment gave the best results 105.48 and 99.74 capsule plant $^{-1}$ without significant differences with the G. glabara L. treatment 104.47 and 101.79 capsule plant $^{-1}$ compared with other treatments especially control treatment which had the lowest mean 83.80 and 81.77 capsule plant $^{-1}$ for two seasons, respectively.

Table 5. Effect of different treatments on the number of capsules plant ${ }^{-1}$ for the seasons 2018 and 2019

\begin{tabular}{|c|c|c|c|c|}
\hline \multicolumn{5}{|c|}{ 2017-2018 } \\
\hline \multirow{2}{*}{$\begin{array}{l}\text { Fertilizer } \\
\text { treatments }\end{array}$} & \multicolumn{3}{|c|}{ Linseed cultivar's } & \multirow{2}{*}{ Mean } \\
\hline & Syrian & Egyptian & Iraqi & \\
\hline Control & 90.81 & 73.33 & 87.25 & 83.80 \\
\hline NPK & 118.83 & 92.71 & 104.91 & 105.48 \\
\hline M. rotundifolia & 96.76 & 76.84 & 86.57 & 86.39 \\
\hline E. crassipes & 110.38 & 82.17 & 101.22 & 97.92 \\
\hline G. glabara & 120.63 & 84.62 & 108.15 & 104.47 \\
\hline S. marianum & 102.63 & 89.78 & 95.24 & 95.89 \\
\hline LSD 0.05 & & 6.85 & & 4.67 \\
\hline Mean & 106.67 & 83.24 & 97.26 & \\
\hline LSD 0.05 & & 2.80 & & \\
\hline \multicolumn{5}{|c|}{ 2018-2019 } \\
\hline Control & 89.56 & 68.93 & 86.81 & 81.77 \\
\hline NPK & 112.20 & 87.63 & 99.40 & 99.74 \\
\hline M. rotundifolia & 97.37 & 74.82 & 83.69 & 85.29 \\
\hline E. crassipes & 98.10 & 76.51 & 97.03 & 90.55 \\
\hline G. glabara & 115.67 & 88.62 & 101.09 & 101.79 \\
\hline S. marianum & 109.60 & 82.74 & 95.01 & 95.78 \\
\hline LSD 0.05 & & 5.73 & & 3.75 \\
\hline Mean & 103.75 & 79.88 & 93.84 & \\
\hline LSD 0.05 & & 2.34 & & \\
\hline
\end{tabular}

The superiority of the G. glabara L. fertilizer treatment could be due to the role of the resulting nutrients in improving the nutritional status of the plant (Table 2) and stimulating vegetative growth by directing growth towards increasing the number of main and sub branches plant $^{-1}$ (Tables 3 and 4). The interaction between cultivars and fertilizer treatments affect significantly on the number of capsules plant ${ }^{-1}$ (Table 5). The Syrian cv. with G. glabara L. treatment gave the highest values 120.63 and 115.67 capsule plant $^{-1}$ without significant differences on the same cultivar with NPK treatment 118.83 and 112.20 capsule plant $^{-1}$, while the Egyptian cv. with control treatment gave the lowest values 73.33 and 68.93 capsule plant $^{-1}$ for the two seasons, respectively.

\section{Number of seeds capsule ${ }^{-1}$}

Results at the Table 6 show that the significantly differences among cultivars in the number of seeds capsule ${ }^{-1}$. The Syrian cv. recorded the highest means 8.03 and 8.33 seed capsule $^{-1}$ compared with other cultivars especially Egyptian cv. which recorded the lowest means 5.86 and 5.89 seed capsule ${ }^{-1}$ for the two seasons, respectively. The differences among cultivars could be due to their genetical components and their response to the environmental conditions. These results are in agreement with Al-Sudani (5) and Andruszczak (6). Data at the Table 6 also show that the number of seeds capsule ${ }^{-1}$ was significantly affected by fertilizer treatments. The NPK treatment had the highest means 7.89 and 7.95 seed capsule ${ }^{-1}$ with nonsignificant differences on the G. glabara L. treatment 7.77 and 7.73 seed capsule ${ }^{-1}$, while the control treatment gave the lowest means 6.27 and 6.61 seed capsule ${ }^{-1}$ for the two seasons, respectively. The increasing in the number of seeds could be due to the positive effect of the NPK application or G. glabara L. treatments in improving the state nutrient of plant, promoting physiological activities including photosynthesis and an increasing 
their metabolic products and transfer to the new sites (primordia) in the reproductive stage of the plant and that led to increase the pollen germination, number of fertilized ovules and then an increasing the number of seeds capsule $^{-1}$ (4).

Table 6. Effect of different treatments on the number of seeds capsule ${ }^{-1}$ for the seasons 2018 and 2019

\begin{tabular}{|c|c|c|c|c|}
\hline \multicolumn{5}{|c|}{ 2017-2018 } \\
\hline \multirow{2}{*}{$\begin{array}{l}\text { Fertilizer } \\
\text { treatments }\end{array}$} & \multicolumn{3}{|c|}{ Linseed cultivar's } & \multirow{2}{*}{ Mean } \\
\hline & Syrian & Egyptian & Iraqi & \\
\hline Control & 6.75 & 4.88 & 7.09 & 6.27 \\
\hline NPK & 8.77 & 6.69 & 8.21 & 7.89 \\
\hline M. rotundifolia & 7.52 & 5.15 & 6.58 & 6.42 \\
\hline E. crassipes & 8.14 & 5.66 & 7.55 & 7.12 \\
\hline G. glabara & 8.98 & 6.17 & 8.17 & 7.77 \\
\hline S. marianum & 8.03 & 6.59 & 7.86 & 7.49 \\
\hline LSD 0.05 & & 0.44 & & 0.30 \\
\hline Mean & 8.03 & 5.86 & 7.58 & \\
\hline LSD 0.05 & & 0.18 & & \\
\hline \multicolumn{5}{|c|}{ 2018-2019 } \\
\hline Control & 7.36 & .025 & 7.44 & 6.61 \\
\hline NPK & 9.15 & 6.65 & 8.06 & 7.95 \\
\hline M. rotundifolia & 7.82 & 5.48 & 6.84 & 6.71 \\
\hline E. crassipes & 8.15 & 5.69 & 7.99 & 7.28 \\
\hline G. glabara & 9.02 & 6.05 & 8.13 & 7.73 \\
\hline S. marianum & 8.45 & 6.46 & 7.80 & 7.57 \\
\hline LSD 0.05 & & 0.52 & & 0.36 \\
\hline Mean & 8.33 & 5.89 & 7.71 & \\
\hline Lsd 0.05 & & 0.21 & & \\
\hline
\end{tabular}

The interaction between two factors was significant effect on the number of seeds capsule $^{-1}$. The Syrian cv. with G. glabara L. treatment recorded the highest values 8.98 and 9.02 seed capsule $^{-1}$ without significant differences on the same cultivar with NPK treatment 8.77 and 9.15 seed capsule ${ }^{-1}$, while the Egyptian cv. with control treatment recorded the lowest values 4.88 and 5.02 seed capsule $^{-1}$ for the two seasons, respectively (Table 6).

\section{Weight of 1000 seeds}

The differences in 1000 seeds weight among cultivars have been found significant (Table 7). The Egyptian cv. gave the highest means 6.73 and $7.22 \mathrm{~g}$ compared with Syrian cv. which gave the lowest means 5.96 and $6.33 \mathrm{~g}$ for the two seasons, respectively. The superiority of the Egyptian cv. could be due to the low number of capsules plant ${ }^{-1}$ and number of seeds capsule ${ }^{-1}$ (Tables 5 and 6) and that led to seed getting a greater amount of metabolic compounds and an increasing its weight. These results are in agreement with Al-Sudani (5) who reported that the Egyptian cv. gave the highest mean of 1000 seeds weight. The results at the Table 7 indicate that the control treatment was significantly superior in the 1000 seeds weight 6.86 and $7.31 \mathrm{~g}$ without significant differences on the $M$. rotundifolia L. treatment 6.78 and $7.46 \mathrm{~g}$ compared with $G$. glabara L. treatment which gave the lowest means 5.95 and $6.52 \mathrm{~g}$ without significant differences on the NPK treatment 6.01 and $6.31 \mathrm{~g}$ for the two seasons, respectively.

Table 7. Effect of different treatments on

the 1000 seeds weight (g) for the seasons 2018 and 2019

\begin{tabular}{|c|c|c|c|c|}
\hline \multicolumn{5}{|c|}{2018} \\
\hline \multirow{2}{*}{$\begin{array}{l}\text { Fertilizer } \\
\text { treatments }\end{array}$} & \multicolumn{3}{|c|}{ Linseed cultivar's } & \multirow[b]{2}{*}{ Mean } \\
\hline & Syrian & Egyptian & Iraqi & \\
\hline Control & 6.63 & 7.20 & 6.76 & 6.86 \\
\hline NPK & 5.68 & 6.28 & 6.05 & 6.01 \\
\hline M. rotundifolia & 6.18 & 7.22 & 6.93 & 6.78 \\
\hline E. crassipes & 5.90 & 6.85 & 6.51 & 6.42 \\
\hline G. glabara & 5.44 & 6.33 & 6.08 & 5.95 \\
\hline S. marianum & 5.92 & 6.47 & 6.21 & 6.20 \\
\hline LSD 0.05 & & N.S & & 0.23 \\
\hline Mean & 5.96 & 6.73 & 6.42 & \\
\hline LSD 0.05 & & 0.12 & & \\
\hline \multicolumn{5}{|c|}{2019} \\
\hline Control & 7.02 & 7.73 & 7.19 & 7.31 \\
\hline NPK & 5.59 & 6.68 & 6.66 & 6.31 \\
\hline M. rotundifolia & 6.83 & 7.92 & 7.62 & 7.46 \\
\hline E. crassipes & 6.53 & 7.23 & 6.91 & 6.89 \\
\hline G. glabara & 5.77 & 7.03 & 6.75 & 6.52 \\
\hline S. marianum & 6.21 & 6.71 & 6.84 & 6.59 \\
\hline LSD 0.05 & & 0.36 & & 0.27 \\
\hline Mean & 6.33 & 7.22 & 7.00 & \\
\hline LSD 0.05 & & 0.15 & & \\
\hline
\end{tabular}

The final weight of the seed depends mainly on the source's ability to supply photosynthesis products during the duration of seed full, in addition to sink capacity to absorb and store the largest amount of metabolites, so the reason of the lowest weight of 1000 seeds in the G. glabara L. or NPK treatments could be due to superior in the number of capsules plant $^{-1}$ and number of seeds capsule ${ }^{-1}$ (Tables 5 
and 6). Further, more greatest number of seeds capsule $^{-1}$ greater competition among them for the metabolic compounds of photosynthesis which leads to the distribution and partitioning of these products to a larger number of seeds and then the seed weight is lower. The interaction between cultivars and fertilizer treatments was significant differences on the 1000 seeds weight in the second season only (Table 7). The Egyptian cv. with $M$. rotundifolia $\mathrm{L}$. treatment gave the highest values $7.92 \mathrm{~g}$ without significant differences on the same cultivar with control treatment $7.62 \mathrm{~g}$ and Iraqi local cv. with M. rotundifolia L. treatment $7.73 \mathrm{~g}$, while the Syrian cv. with NPK treatment gave the lowest values $5.59 \mathrm{~g}$ without significant differences on the same cultivar with G. glabara L. treatment $5.77 \mathrm{~g}$.

\section{Seeds yield}

The seed yield differences among cultivars were significant (Table 8). The Syrian cv. had the highest means 1.03 and 1.12 mton $^{-1}$ while the Egyptian cv. produced the lowest means 0.78 and $0.75 \mathrm{mton}^{\mathrm{h}} \mathrm{a}^{-1}$ for the two seasons, respectively. The superiority of the Syrian cv. could be due to superiority in the number of capsules plant ${ }^{-1}$ and number of seeds capsules ${ }^{-1}$ (Tables 5 and 6). These results are in agreement with Al-Sudani (5), Gallardo et al., (12) and Zamir et al., (19). Data at the Table 8 show that the seed yield was significantly affected by fertilizer treatments. The G. glabara L. treatment had the highest means 1.04 and 1.03 mton $\mathrm{ha}^{-1}$ without significant differences on the NPK treatment 1.01 and 1.07 mton $\mathrm{ha}^{-1}$, while the control treatment had the lowest means 0.77 and 0.83 mton $\mathrm{ha}^{-1}$ for the two seasons, respectively. The superiority of the G. glabara L. or NPK treatments could be due to the increase in the number of capsules plant ${ }^{-1}$ and number of seeds capsule $^{-1}$ (Tables 5 and 6). The interaction between cultivars and fertilizer treatments was significant effect on the seed yield. Data in Table 8 show that the Syrian cv. with G. glabara L. treatment had the highest values 1.28 and 1.29 mton $\mathrm{ha}^{-1}$ without significant differences on the same cultivar with NPK treatment 1.20 and 1.30 mton ha $^{-1}$, while the Egyptian cv. with control treatment gave the lowest values 0.66 and $0.63 \mathrm{mton} \mathrm{ha}^{-1}$ for the two seasons, respectively.

Table 8. Effect of different treatments on the seeds yield (mton ha ${ }^{-1}$ ) for the seasons 2018 and 2019

\begin{tabular}{|c|c|c|c|c|}
\hline \multicolumn{5}{|c|}{ 2017-2018 } \\
\hline \multirow{2}{*}{$\begin{array}{l}\text { Fertilizer } \\
\text { treatments }\end{array}$} & \multicolumn{3}{|c|}{ Linseed cultivar's } & \multirow{2}{*}{ Mean } \\
\hline & Syrian & Egyptian & Iraqi & \\
\hline Control & 0.84 & 0.66 & 0.82 & 0.77 \\
\hline NPK & 1.20 & 0.87 & 0.96 & 1.01 \\
\hline M. rotundifolia & 0.88 & 0.73 & 0.77 & $\mathbf{0 . 8 0}$ \\
\hline E. crassipes & 0.97 & 0.77 & 0.88 & 0.87 \\
\hline G. glabara & 1.28 & 0.81 & 1.02 & 1.04 \\
\hline S. marianum & 1.03 & 0.84 & 0.95 & 0.94 \\
\hline LSD 0.05 & & 0.08 & & 0.05 \\
\hline Mean & 1.03 & 0.78 & 0.90 & \\
\hline LSD 0.05 & & 0.03 & & \\
\hline \multicolumn{5}{|c|}{ 2018-2019 } \\
\hline Control & 0.92 & 0.63 & 0.94 & 0.83 \\
\hline NPK & 1.30 & 0.88 & 1.04 & 1.07 \\
\hline M. rotundifolia & 0.99 & 0.69 & 0.86 & 0.85 \\
\hline E. crassipes & 1.04 & 0.72 & 1.01 & 0.92 \\
\hline G. glabara & 1.29 & 0.77 & 1.03 & 1.03 \\
\hline S. marianum & 1.17 & 0.80 & 0.97 & 0.98 \\
\hline LSD 0.05 & & 0.06 & & 0.04 \\
\hline Mean & 1.12 & 0.75 & 0.98 & \\
\hline LSD 0.05 & & 0.03 & & \\
\hline
\end{tabular}

\section{Biological yield}

Results at the Table 9 indicate that the cultivars was differed significantly in the biological yield. The Syrian cv. recorded the

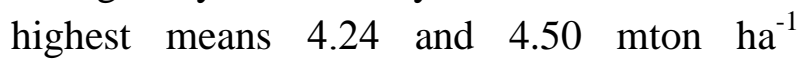
compared with other cultivars especially Egyptian cv. which recorded the lowest means 3.61 and 3.82 mton $^{-1}$ for the two seasons, respectively. The superiority of the Syrian cv. in two yield components and seed yield (Tables 5, 6 and 8) could be led to increases of biological yield. These results are in agreement with Al-Sudani (5) and Bakry et al., (7) who pointed that the different genetic nature of linseed cultivars had different response to environmental conditions with reflect on the growth and development of plants and their ability to exploit growth factors and direct them towards increasing 
physiological activities, including photosynthesis and its metabolic products and then increasing the accumulation of dry matter in the plant.

Table 9. Effect of different treatments on the biological yield (mton ha ${ }^{-1}$ ) for the seasons 2018 and 2019

\begin{tabular}{|c|c|c|c|c|}
\hline \multicolumn{5}{|c|}{ 2017-2018 } \\
\hline \multirow{2}{*}{$\begin{array}{l}\text { Fertilizer } \\
\text { treatments }\end{array}$} & \multicolumn{3}{|c|}{ Linseed cultivar's } & \multirow{2}{*}{ Mean } \\
\hline & Syrian & Egyptian & Iraqi & \\
\hline Control & 3.80 & 3.40 & 3.82 & 3.68 \\
\hline NPK & 4.49 & 3.82 & 4.18 & 4.16 \\
\hline M. rotundifolia & 3.93 & 3.48 & 3.67 & 3.70 \\
\hline E. crassipes & 4.19 & 3.62 & 3.82 & 3.88 \\
\hline G. glabara & 4.69 & 3.65 & 4.20 & 4.18 \\
\hline S. marianum & 4.32 & 3.72 & .044 & 4.03 \\
\hline LSD 0.05 & & 0.21 & & 0.14 \\
\hline Mean & 4.24 & 3.61 & 3.96 & \\
\hline LSD 0.05 & & 0.09 & & \\
\hline \multicolumn{5}{|c|}{ 2018-2019 } \\
\hline Control & 4.10 & 3.54 & 4.12 & 3.92 \\
\hline NPK & 4.82 & 4.02 & 4.36 & 4.40 \\
\hline M. rotundifolia & 4.29 & 3.68 & 3.96 & 3.98 \\
\hline E. crassipes & 4.45 & 3.79 & 4.31 & 4.18 \\
\hline G. glabara & 4.71 & 3.91 & 4.35 & 4.32 \\
\hline S. marianum & 4.61 & 3.95 & 4.28 & 4.28 \\
\hline LSD 0.05 & & 0.18 & & 0.11 \\
\hline Mean & 4.50 & 3.82 & 4.23 & \\
\hline LSD 0.05 & & 0.07 & & \\
\hline
\end{tabular}

Results at the Table 9 show that the biological yield was significantly affected by fertilizer treatments. The G. glabara L. treatment had the highest means 4.18 and 4.32 mton ha ${ }^{1}$ without significant differences on the NPK treatment 4.16 and $4.40 \mathrm{mton} \mathrm{ha}^{-1}$, while the control treatment gave the lowest means 3.68

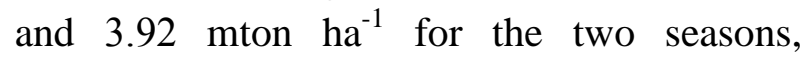
respectively. The results were showed that the application of $G$. glabara L. or NPK treatments effectively contributed in an increase the number of main and sub branches plant $^{-1}$ (Table 3 and 4), which means an increasing the efficiency of photosynthesis process and increasing the accumulation of dry matter and that led to increase of the number of capsules plant ${ }^{-1}$, number of seeds capsule ${ }^{-1}$ and seed yield. (Tables 5, 6 and 8) and finally increasing the biological yield. The interaction between two factors was significant effect on the biological yield (Table 9). The Syrian cv. with $G$. glabara L. treatment recorded the highest values 4.69 and $4.71 \mathrm{mton} \mathrm{ha}^{-1}$ without significant differences on the same cultivar with NPK treatment 4.49 and 4.82 mton ha $^{-1}$, while the Egyptian cv. with control treatment recorded the lowest values 3.40 and 3.54 mton $\mathrm{ha}^{-1}$ for the two seasons, respectively.

\section{Harvest index}

Results in Table 10 show that there are significant differences among linseed cultivars in the harvest index. The Syrian cv. gave the highest means 24.21 and $24.82 \%$ compared with Iraqi local cv. and Egyptian cv. which gave the lowest means 21.56 and $19.60 \%$ for the two seasons, respectively.

Table 10. Effect of different treatments on the harvest index (\%) for the seasons 2018

\begin{tabular}{|c|c|c|c|c|}
\hline \multicolumn{5}{|c|}{ and 2019} \\
\hline \multicolumn{5}{|c|}{ 2017-2018 } \\
\hline \multirow{2}{*}{$\begin{array}{l}\text { Fertilizer } \\
\text { treatments }\end{array}$} & \multicolumn{3}{|c|}{ Linseed cultivar's } & \multirow{2}{*}{ Mean } \\
\hline & Syrian & Egyptian & Iraqi & \\
\hline Control & 22.16 & 19.42 & 21.35 & 20.98 \\
\hline NPK & 26.72 & 22.77 & 22.89 & 24.13 \\
\hline M. rotundifolia & 22.48 & 21.02 & 20.94 & 21.48 \\
\hline E. crassipes & 23.01 & 21.31 & 22.99 & 22.44 \\
\hline G. glabara & 27.19 & 22.32 & 24.20 & 24.57 \\
\hline S. marianum & 23.69 & 22.54 & 23.50 & 23.24 \\
\hline LSD 0.05 & & 1.12 & & 0.85 \\
\hline Mean & 24.21 & 21.56 & 22.64 & \\
\hline LSD 0.05 & & 0.46 & & \\
\hline \multicolumn{5}{|c|}{ 2018-2019 } \\
\hline Control & 22.35 & 17.88 & 22.82 & 21.02 \\
\hline NPK & 27.02 & 21.84 & 23.79 & 24.21 \\
\hline M. rotundifolia & 23.23 & 18.80 & 21.79 & 21.27 \\
\hline E. crassipes & 23.42 & 18.94 & 23.45 & 21.94 \\
\hline G. glabara & 27.43 & 19.80 & 23.73 & 23.65 \\
\hline S. marianum & 25.48 & 20.36 & 22.80 & 22.88 \\
\hline LSD 0.05 & & 1.55 & & 1.05 \\
\hline Mean & 24.82 & 19.60 & 23.06 & \\
\hline LSD 0.05 & & 0.63 & & \\
\hline
\end{tabular}

The harvest index represents the ratio of seed to biological yield, and refers to the efficiency of dry matter conversion from sources to sinks, so the reason of superiority the Syrian cv. could be due to its superiority in seed yield and biological yield (Tables 8 and 9). These results are in agreement with Al-Sudani (5) and Raju (16). Data in Table 10 showed that the harvest index was significantly affected by fertilizer treatments. The G. glabara L. 
treatment had the highest means 24.57 and $23.65 \%$ without significant differences on the NPK treatment 24.13 and $24.21 \%$, while the control treatment had the lowest means 20.98 and $21.02 \%$ for the two seasons, respectively. The superiority of the G. glabara L. or NPK treatments could be due to their positive role in dry matter accumulation and transport from sources to sinks and then an increasing seed yield and biological yield (Tables 8 and 9). The interaction between two factors was significant effects on the harvest index (Table 10). The Syrian cv. with G. glabara L. treatment gave the highest values 27.19 and $27.43 \%$ without significant differences on the same cultivar with NPK treatment 26.72 and $27.02 \%$, while the Egyptian cv. with control treatment gave the lowest values 19.42 and $17.88 \%$ for the two seasons, respectively.

\section{REFERENCES}

1. Al-Hasanie, L. N. H. and A. D. AlMaadhedi. 2017. Influence of irrigation periods and organic fertilizer on tow rice vsrieties grown under the rsystem of rice intensification (SRI). Iraqi J. Agric. Sci. 48(3): 823-840.

2. Al-Hilfy, I. H. H. and M. I. Flayyah. 2017. Response of two bread wheat varieties yield to mineral, bio-and organic fertilizers. Iraqi $\mathrm{J}$. Agric. Sci. 48(6): 1661-1671.

3. Ali, N. S. and A. A. Shaker. 2018. Organic Fertilization and It's Role in Sustainable Agriculture. Scientific Books House Publ., Baghdad, Iraq. pp. 216.

4. Allen, V. B. and D. J. Pilbeam. 2006. Plant Nutrition. Department of Plant Sci. Unin. of Massa-Chusetts. p. 293-328.

5. Al-Sudani, E. Kh. F. 2018. Effect of Bio Fertilization on Linseed Yield and Oil Qualities. M.Sc. Thesis, Dept. of Field Crops, Coll. of Agric. Engin. Sci. Univ. of Baghdad. pp. 99.

6. Andruszczak, S.; U. Gawlik-Dziki; P. Kraska; E. Kwiecińska-Poppe; K. Różyło and E. Pałys. 2015 .Yield and quality traits of two linseed (Linum usitatissimum L.) cultivars as affected by some agronomic factors. Plant Soil Environ. 61(6): 247-252.

7. Bakry, A. B.; M. H. Taha; Z. A. Abdelgawad and M. M. S. Abdallah. 2014. The role of humic acid and proline on growth, chemical constituents and yield quantity and quality of three flax cultivars grown under saline soil conditions. J. of Agric. Sci. 5: 15661575.

8. Dahama, A. K. 1999. Organic Farming for Sustainable Agriculture. Agro Bola Nice, Daryagun, New Delhi.

9. Dhary, S. I. and M. H. K. Al-Baldawi. 2017. Response of different varieties of faba bean to plant source organic fertilizers. Iraqi J. Agric. Sci. 48(4): 1148-1157.

10. Donald, C. M. 1962. In search of yield. J. Aust. Inst. Agric. Sci. 28: 495-499.

11. Elsahookie, M. M. 1978. Effects of varying row spacing on linseed yield and quality. Can. J. Plant Sci. 58: 935-931.

12. Gallardo, M. A.; H. J. Milisich; S. R. Drago and R. J. González. 2014. Effect of cultivars and planting date on yield, oil content, and fatty acid profile of flax varieties (Linum usitatissimum L.). Intl. J. of Agron. 10: 2-7.

13. Gupta, M.; S. Kour; V. Gupta; R. Bharat and C. Sharma. 2017. Effect of different doses of fertilizers on yield and NPK uptake of linseed (Linum usitatissimum L.). Bangladesh J. Bot. 46(2): 575-581.

14. Mohammed Ali, Kh. I.; A. A. A. AlJubori; M. H. K. Al-Baldaw and Z. A. Abdul Al-Majeed. 2010. Field Crops Production. $1^{\text {st }}$ Edn., Alwaquf Al-Haditha Press. pp. 285.

15. Piccolo, A.; S. Nardi and G. Concheri. 1992. Structural characteristics of humic substance as related to nitrate uptake and growth regulation in plant systems. Soil Biol. Biochem. 24: 373-380.

16. Raju, G. S. 2018. Response of Linseed (Linum usitatissimum L.) Varieties to Different Spacing And Fertilizer Levels. M.Sc. Thesis, Agron. Section, Coll. of Agric. pp. 89. 
17. Steel, R. G. and Y. H. Torrie. 1960. Principles and Procedures of Statistics. Mc Grow - Hill Book Co., Inc. New York. pp. 480.

18. Storlien, L.; A. J. Hulbert and P. L. Else. 1998. Polyunsaturated fatty acids, membrane function and metabolic diseases such as diabetes and obesity. Curr. Opin. Clinical Nutrition and Metabolic Care. 1: 559-563.
19. Zamir, S. I.; M. Hussain; M. Z. Irshad; H. M. R. Javeed; Q. Zaman; H. Younis; H. Fatima; F. Tabssum; M. Nisa; A. Mustafa; A. R. Ashraf, Q. Saeed and F. Sufyan. 2016. Exploring the qualitative and quantitative response of various linseed cultivars under different nitrogen levels. Transylvanian Rev. 24(11) Special Issue: 3180-3186.

20. Zhang, L.; S. Shen and W. Yu. 2003. A Long term field trial on fertilization and on use of recycled nutrients in farming. Wing Wong Sheng Tai Xue Bao. 13(11): 1431-1436. 